\title{
Effects of Malting and Fermentation on Anti-Nutrient Reduction and Protein Digestibility of Red Sorghum, White Sorghum and Pearl Millet
}

\author{
C. A. Onyango ${ }^{1}$, S. O. Ochanda ${ }^{1}$, M. A. Mwasaru ${ }^{1}$, J. K Ochieng ${ }^{2}$, F. M. Mathooko ${ }^{3} \&$ J. N. Kinyuru ${ }^{1}$ \\ ${ }^{1}$ Department of Food Science, Jomo Kenyatta University of Agriculture and Technology, Nairobi, Kenya \\ ${ }^{2}$ Ministry of Agriculture, Mwingi District, Agriculture Office, Mwingi, Kenya \\ ${ }^{3}$ South Eastern University College, Kitui, Kenya \\ Correspondence: C. A. Onyango, Department of Food Science, Jomo Kenyatta University of Agriculture and \\ Technology, P. O. Box 62000-00200, Nairobi, Kenya. E-mail: cakoth2002@yahoo.co.uk
}

Received: October 29, 2012 Accepted: November 16, 2012 Online Published: January 15, 2013

doi:10.5539/jfr.v2n1p41 URL: http://dx.doi.org/10.5539/jfr.v2n1p41

\begin{abstract}
Sorghum and millet and their products require specialized treatment in order to improve their nutritive value, organoleptic properties and shelf-life. They contain anti-nutrients which are the major phytochemicals which negatively affects their nutritive values. The phytochemicals of concern include tannins and phytates, which interfere with mineral absorption, palatability and protein digestibility. Malting and fermentation treatments were applied to reduce the anti-nutrients, improve protein digestibility, and acidity to increase the products shelf life. The effects of malting and fermentation on the cereals nutritive value and anti-nutrient reduction were studied and evaluated for a period of 8 days. A treatment combining malting for 3 days and fermentation for 2 days respectively both at room temperatures $\left(25^{\circ} \mathrm{C}\right)$ was employed. Tannins and phytates were significantly reduced $(\mathrm{p} \leq 0.05)$ by malting and fermentation. Protein digestibility was significantly $(\mathrm{p} \leq 0.05)$ improved by malting and fermentation treatments; malted cereals digestibility ranged between $34.5-68.1 \%$ while the fermented flours protein digestibility range was $97.4-98.3 \%$. The $\mathrm{pH}$ values were lowered to below 4.0 , a level at which they could effectively inhibit spoilage microorganisms at the end of the fermentation period. A combination of optimum time treatments of malting and fermentation for 3 days and 2 days respectively were effective in reducing tannins and phytates and improving protein digestibility of the cereals.
\end{abstract}

Keywords: phytates, tannins, malting, fermentation, protein digestibility

\section{Introduction}

Sorghum and millet provide nutrition to many people living in arid and semi-arid lands (ASAL) according to FAO (1995). This is because these crops do well both in areas with adequate rain as well as in ASAL regions. More than 95\% of total food use of sorghum occurs in Africa and Asia (FAO, 1995; Doggett, 1988). FAO (1995) indicated that despite of the increase in total food use, there has been a decline in the utilization of sorghum and millet since early 1960s in both Asia and Africa. This decline in per capita consumption is partly due to shifts in consumer habits brought about by poor palatability of some varieties, low digestibility of protein, low nutritive value of the grains among other factors (Butler, 1984; 1988). Palatability can be improved by reducing tannin levels in affected varieties while digestibility and nutrient availability of grains can be improved by malting and fermentation processes (Dassenko, 1980; Ejeta, 1987). Many research findings have shown that fermentation imparts several invaluable attributes to food products. Fermented foods have many beneficial products metabolized by bacteria and fungi including biomass proteins, amino acids, vitamins, minerals, flavor and aroma compounds among others. (Annan et al., 2003; Au \& Fields, 1981; Baghel et al., 1985; Beaumount, 2002; Carter \& Carpenter, 1981; 1982; Deshpande \& Salunke, 2002; Steinkraus, 1996; Yasmine, 2002). Malting and fermentation may decrease anti-nutrients and increase protein digestibility (Dhankher \& Chauhan, 1987; Gibson, 1994; Mosha, 1994; Ochanda et al., 2010; Steinkraus, 1983, Udayasekhara et al., 1988; West et al., 2002).

\subsection{Germination}

Germination increases endogenous phytase activity in cereals, legumes, and oil seeds through De Novo synthesis, activation of intrinsic phytase, or both. Tropical cereals such as maize and sorghum have a lower endogenous 
phytase activity than do rye, wheat, triticale, buckwheat, and barley (Egli et al., 2002). Certain tannins and other polyphenols in legumes such as Vicia faba and red sorghum may also be reduced during germination as a result of the formation of polyphenol complexes with proteins and the gradual degradation of oligosaccharides (Camacho et al., 1992). Such reductions in polyphenols may facilitate iron absorption (Hurrell, 2004).

\subsection{Fermentation}

Natural fermentation induces phytate hydrolysis via the action of microbial phytase enzymes originating from the microflora on the surface of cereals and legumes, thereby reducing the phytates (Sandberg et al., 1991; Hurrell, 2004). Fermentation imparts other invaluable attributes of food products. Fermented food has many beneficial products metabolized by bacteria and these include biomass proteins, amino acids, vitamins, minerals, flavor and aroma compounds and carbohydrates. Products of respiratory and biosynthetic pathways such as lactic acid, ethanol, acetaldehyde and pyruvic acid are also produced which alters the $\mathrm{pH}$ of foods to levels that they control the growth of pathogenic microorganisms. This therefore enhances food safety and shelf life thus aiding in food preservation (Annan et al., 2003; Au \& Fields, 1981; Baghel et al., 1985; Beaumount, 2002; Deshpande \& Salunke, 2002; Steinkraus, 1996; Yasmine, 2002).

\section{Materials and Methods}

\subsection{Materials}

The varieties of the sorghums, Sorghum bicolor (L) Moench acquired were white sorghum -KARI Mtama 1 (KM1) and the red sorghum-Seredo. The pearl millet Pennisetum glaucum variety was ICMV. The sorghum and millet varieties were obtained from Mwingi district one of the Arid and semi-arid Land areas of Kenya. The cereals were sampled form batches of two different years, 2007 and 2008 which were provided by farmers from their cereal stores. Grains $(2 \mathrm{kgs})$ from several, farmers were acquired and mixed to form uniform representative samples for analysis.

\subsection{Sample Preparation}

Malting of the cereals was done by steeping for $24 \mathrm{hrs}$ at $25^{\circ} \mathrm{C}$ and germination for $72 \mathrm{hrs}$ at $25^{\circ} \mathrm{C}$. Samples were sun-dried to a moisture content of $13 \%$. The rootlets were removed by pounding, the grains milled and tannin, phytates and protein digestibility assays done.

Fermentation was through the natural way by allowing environmental microflora to colonize the cereal flours and cause lactic acid fermentation. Grains were milled and flours mixed with water at a ratio of 1:3 to form slurries which were fermented at room temperatures of $25^{\circ} \mathrm{C}$ for $48 \mathrm{hrs}$. Following fermentation, tannin and phytate determination, protein-digestibility, $\mathrm{pH}$ and acidity levels were determined.

\subsection{Determination of Tannins}

This was done according to vanillin-hydrochloric acid method (Burns, 1963) modified by Price et al., (1978). Approximately $0.25 \mathrm{~g}$ of ground samples were weighed into Erlenmeyer flasks. Ten (10) $\mathrm{ml}$ of $4 \% \mathrm{HCl}$ in methanol was pipetted into each of the flasks and closed with parafilm. The flasks were gently shaken for $20 \mathrm{~min}$ in a shaker (Model KS 250 basic, Germany) and the resulting extracts centrifuged for 10 min at $4500 \mathrm{rpm}$ (Model H-2000C, Kokusan Corp., Tokyo, Japan). The supernatant aliquots were transferred to $25 \mathrm{ml}$ volumetric flasks. Second extractions were done by adding $5 \mathrm{ml}$ of $1 \% \mathrm{HCl}$ in methanol to the residue from the first extraction and the extraction process repeated. The aliquots of the first and second extractions were combined and made up to $25 \mathrm{ml}$ volume. Approximately $1 \mathrm{ml}$ of each extract was pipetted to a corresponding labeled test tube. A set of catechin standard solutions was prepared ranging from 100 to $1000 \mathrm{ppm}$ using methanol. Approximately $1 \mathrm{ml}$ of each respective standard and sample extract were pipetted into test tubes and $5 \mathrm{ml}$ of freshly prepared vanillin- $\mathrm{HCl}$ reagent added. Sample blanks were prepared by adding $5 \mathrm{ml}$ of $4 \% \mathrm{HCl}$ in methanol to $1 \mathrm{ml}$ of the aliquot extracts in test tubes. The absorbencies of the standard solutions, sample extracts and blanks were read in a UV-VIS spectrophotometer (UV mini 1240 model, Shimadzu Corp., Kyoto Japan) at $500 \mathrm{~nm} 20 \mathrm{~min}$ after adding Vanillin-HCl reagent to the samples and standards.

A standard curve was prepared from the readings of the catechin standard solutions. The blank absorbance was subtracted from the samples absorbance and the corrected absorbance substituted into the regression equation ( $\mathrm{y}$ $=0.0004 \mathrm{x}, \mathrm{R}=0.9972$ ) in order to calculate the concentration of the sample extracts.

The concentration in $\mu \mathrm{g}$ per $\mathrm{ml}$ was converted in to $\mathrm{mg}$ catechin per $\mathrm{ml}$. The percent catechin equivalents $(\% \mathrm{CE})$ were calculated as follows:

$$
\% \mathrm{CE}=(\mathrm{CC} \times \mathrm{VM}) /(\mathrm{VE} \times \mathrm{Wt}) \times 100
$$


Where: $\mathrm{CC}=$ catechin concentration $(\mathrm{mg} / \mathrm{ml}) ; \mathrm{VM}=$ volume made up $(25 \mathrm{ml}) ; \mathrm{VE}=$ volume of extract $(1 \mathrm{ml})$; and $\mathrm{Wt}=$ weight of sample $(250 \mathrm{mg})$.

\subsection{Determination of Phytates}

This was done by HPLC method of phytic acid according to Camire and Clydesdale (1982). Approximately 50 $\mathrm{mg}$ of sample was weighed into a $125 \mathrm{ml}$ Erlenmeyer flask and $10 \mathrm{ml}$ of $3 \% \mathrm{H}_{2} \mathrm{SO}_{4}$ added. The flasks were placed on a shaker at a moderate speed for $30 \mathrm{~min}$ at room temperature and filtered using a fast filter paper (Shaker Model KS 250 basic, Germany). The filtrate was transferred to a boiling water bath (BWB) for 5 min and $3 \mathrm{ml}$ of $\mathrm{FeCl}_{3}$ solution (6mg ferric iron per $\mathrm{ml}$ in $3 \% \mathrm{H}_{2} \mathrm{SO}_{4}$ ) added. A second BWB heating was done for 45 min to complete precipitation of the ferric phytate complex. Centrifugation followed at $2500 \mathrm{rpm}$ for $10 \mathrm{~min}$ and the supernatant discarded (Centrifuge Model H-2000C, Shimadzu Corp., Kyoto, Japan). The precipitate was washed with $30 \mathrm{ml}$ distilled water, centrifuged and the supernatant discarded. Three (3) $\mathrm{ml}$ of $1.5 \mathrm{~N} \mathrm{NaOH}$ were added to the residues and the volume brought to $30 \mathrm{ml}$ with distilled water. Heating was done for $30 \mathrm{~min}$ in a BWB to precipitate the ferric hydroxide. Cooled samples were centrifuged and the supernatant transferred into a $50 \mathrm{ml}$ volumetric flask. The precipitate was rinsed with $10 \mathrm{ml}$ distilled water, centrifuged and the supernatant added to the contents of the volumetric flask.

Samples of $20 \mu 1$ volume of the supernatant were injected into a HPLC (Model C-R7A plus, Shimadzu Corp., Kyoto, Japan) fitted with a $50377 \mathrm{RP}-18(5 \mu \mathrm{m})$ column cartridge at an oven temperature of $30^{\circ} \mathrm{C}$ and an RID detector (Model RID-6A, Shimadzu Corp., Kyoto, Japan) used for identification. The mobile phase was $0.005 \mathrm{~N}$ sodium acetate in distilled water, flowing at a flow rate of $0.5 \mu 1 \mathrm{~min}^{-1}$.

A stock solution of the standard containing $10 \mathrm{mg} / \mathrm{ml}$ of sodium phytate (Inositol hexaphosphoric acid $\left.\mathrm{C}_{6} \mathrm{H}_{6}\left(\mathrm{OPO}_{3} \mathrm{Na}_{2}\right)_{6}+\mathrm{H}_{2} \mathrm{O}\right)$ in distilled water was prepared. Serial dilutions were made for the preparation of a standard curve. Results of phytate content were obtained as per the calculations of Vohra et al. (1965). The equation of the standard curve line was obtained $(y=263.13 x, R=0.9938)$ and used for calculating the phytate values as follows;

$$
\text { Phytate content }(\mathrm{mg} / \mathrm{g})=(\mathrm{y} / \mathrm{b}) *(\text { dilution factor / weight of sample })
$$

Where $y$ is the $y$ intercept of obtained from the standard curve of phytates, and $b$ is the peak area of the injected sample.

\subsection{Determination of Protein Digestibility}

Protein digestibility was determined according to the method described by Mertz et al. (1984). This method involved determination of the protein content of sample before and after pepsin enzyme digestion. Malted, fermented samples and a sample combining both malted and fermented were assayed.

The pepsin digestion involved weighing $0.2 \mathrm{~g}$ of ground sample that was passed through a $0.4 \mathrm{~mm}$ screen and adding $35 \mathrm{ml}$ of $0.1 \mathrm{M}$ phosphate buffer: $\mathrm{pH} 2$ containing $1.5 \mathrm{mg}$ pepsin $/ \mathrm{ml}$. Incubation of the pepsin-sample mixture was done at $37^{\circ} \mathrm{C}$ for $2 \mathrm{hrs}$ with continuous gentle shaking. The suspension was then centrifuged at 4800 rpm (Centrifuge Model H-2000C, Shimadzu Corp., Kyoto, Japan) at $4^{\circ} \mathrm{C}$ for 20 min. The supernatant was discarded and the residue washed with $15 \mathrm{ml}$ of $0.1 \mathrm{M}$ phosphate buffer: $\mathrm{pH} 7$ followed by centrifugation as previously done. The supernatant was again discarded and the residue washed on Whatman's No. 3 filter paper in a Buchner funnel. The filter paper containing the undigested protein residue was folded, placed in a digestion tube and dried for $2 \mathrm{hrs}$ at $80^{\circ} \mathrm{C}$.

Control samples of non-fermented and non-germinated cereals and blanks prepared, pepsin digested and protein content determined using the AOAC (AOAC, 1995, Method 20.87-32.1.22) method.

Calculation: Percentage protein digestibility $=(\mathrm{A}-\mathrm{B}) / \mathrm{A}$

Where: $\mathrm{A}=\%$ protein in the sample; and $\mathrm{B}=\%$ protein factor after pepsin digest

\subsection{Determination of $\mathrm{pH}$}

This was done by the method of Ofori and Hahn (1994). The pH meter (TOA pH Meter HM-7B, Tokyo, Japan) was standardized using buffer solutions of acidic and basic values of 4.01 and 9.08 at $25^{\circ} \mathrm{C}$. The electrode was rinsed with distilled water before taking measurements. The fermented samples, (slurry mixtures of flour and water in the ratio of $1: 3$ ) were homogenized by stirring to achieve uniformity. $\mathrm{pH}$ readings were taken by dipping the electrode in the fermented mix and measurements taken from the display screen when the readings stabilized.

\subsection{Determination of Total Titratable Acidity (TTA)}

TTA analysis was done using AOAC (1995) method. Approximately $10 \mathrm{ml}$ of sample was pipetted into a conical flask and 2 drops of phenolphthalein indicator used. Titration was done using $0.1 \mathrm{~N} \mathrm{NaOH}$ to a faint pink colour 
for at least one min (compared against a white background). The titre volume was noted and used for calculations of TTA which was expressed as percentage lactic acid. Calculations of TTA was determined and expressed as follows:

$$
\% \text { Lactic acid }=\mathrm{A} \times 0.009 \times 100 / \mathrm{V}
$$

Where: $\mathrm{A}=\mathrm{ml}$ of $0.1 \mathrm{NaOH}$ required for the titration; and $\mathrm{V}=\mathrm{ml}$ of sample taken for the test. 0.009 is a Constant.

\subsection{Data Analysis}

Variations between malting and fermentation treatments with respect to tannin, phytates and protein digestibility among the cereals was determined using ANOVA and means separated using Duncan's Multiple range test. SAS statistical package was used. Results are given as mean \pm SD (Snedecor \& Cochran, 1987).

\section{Results and Discussion}

\subsection{Effect of Malting and Fermentation on Tannins and Phytates}

There were significant differences in anti-nutrient reduction with malting and fermentation $(\mathrm{p} \leq 0.05)$. Phytate reduction range was 20-21\% with 2 days of fermentation and 19-33\% with 3 days of malting (Figures 1 (a) and (b); Figures 2 (a) and (b)). High tannin content inhibits phytase activity. This renders fermentation less effective in reducing anti-nutrients in cereals such as bulrush millet and red sorghum (Sandberg, 1991). For fermentation to be effective in reducing the anti-nutrients it should be carried on grains with low levels of the anti-nutrients. These could be varieties with low anti-nutrient levels or decorticated grains; alkali treated grains or malted grains. At low anti-nutrient levels, fermentation induces phytate hydrolysis to lower inositol phosphates which have a negative effect on zinc and iron absorption (Lönnerdal et al., 1989).
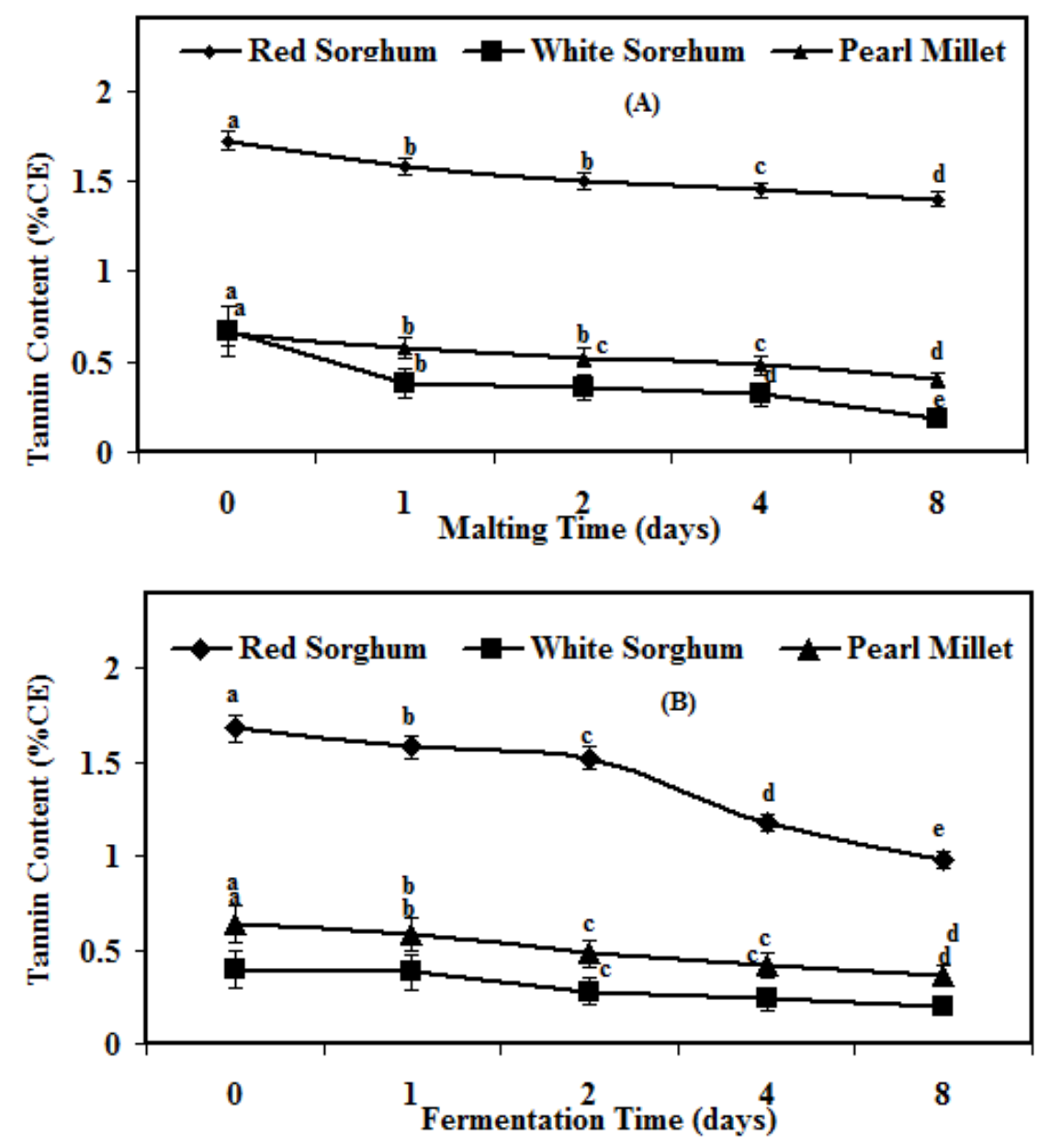

Figure 1. Effect of malting (a) and fermentation (b) on tannin content of cereals. Points on the same curve with similar letter(s) have means that are not significantly different $(\mathrm{p} \geq 0.05)$ 

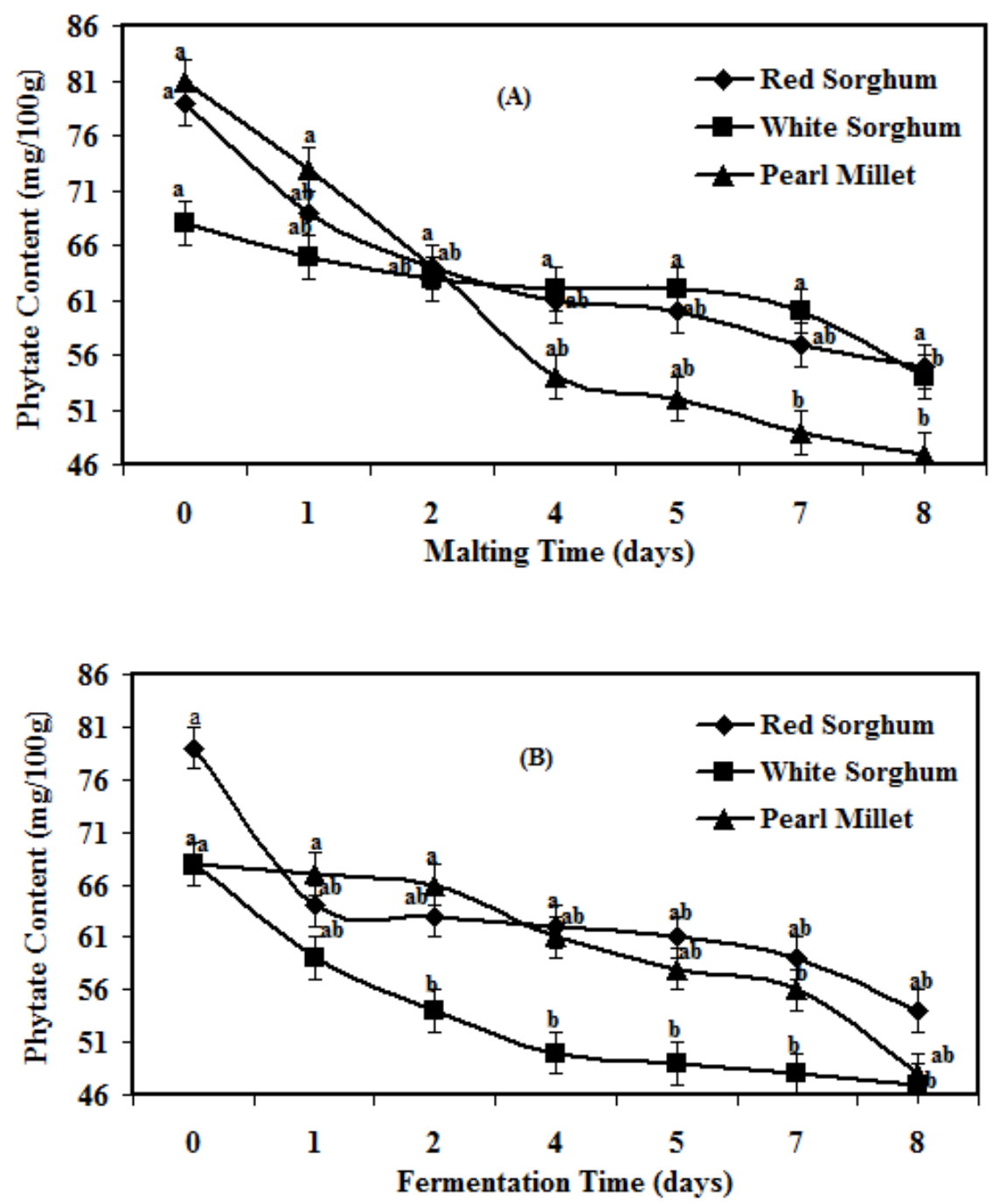

Figure 2. Effect of malting (a) and fermentation (b) on phytate content of the cereals. Points on the same curve with similar letter(s) have means that are not significantly different $(\mathrm{p} \geq 0.05)$

\subsection{Effect of Malting and Fermentation on Protein Digestibility}

Figure 3 shows percentage protein digestibility of malted and fermented cereals compared to the control. There were significant differences $(\mathrm{p} \leq 0.05)$ in the protein digestibility of the control, malted and fermented cereals. Pearl millet had the least digestibility $(21.5 \%)$ among the three cereals while white sorghum had the highest digestibility $(51.7 \%)$. These findings were in agreement with work by other similar research (Aliya \& Geervan, 1981). Malting for $24 \mathrm{hrs}$ significantly $(\mathrm{p} \leq 0.05)$ increased protein digestibility of the cereals. Pearl millet's digestibility increased from $21.5 \%$ to $34.5 \%$ and red sorghum from $48 \%$ to $68.1 \%$. Fermentation also significantly increased the protein digestibility of the cereals $(\mathrm{p} \leq 0.05)$. The range was from $97.4 \%$ to $98.3 \%$ in red and white sorghum respectively. A combination of malting and fermentation produced highly digestible flours which were significantly $(\mathrm{p} \leq 0.05)$ different from the control and malted flours but not from fermented flours. The cereals used were detoxified using alkali treatment followed by malting and then fermentation.

\subsection{Effects of Fermentation on $\mathrm{pH}$ and Total Titratable Acidity (TTA)}

The TTA of the fermented gruels increased as the $\mathrm{pH}$ of the ferments gradually reduced with increase in fermentation time, Figures 4(a) and (b). There were significant increments in TTA and $\mathrm{pH}(\mathrm{p} \leq 0.05)$ from day 0 to day 2 in all the cereals. The changes from day 2 onwards were less rapid though they were still significant $(\mathrm{p} \leq$ $0.05)$. 


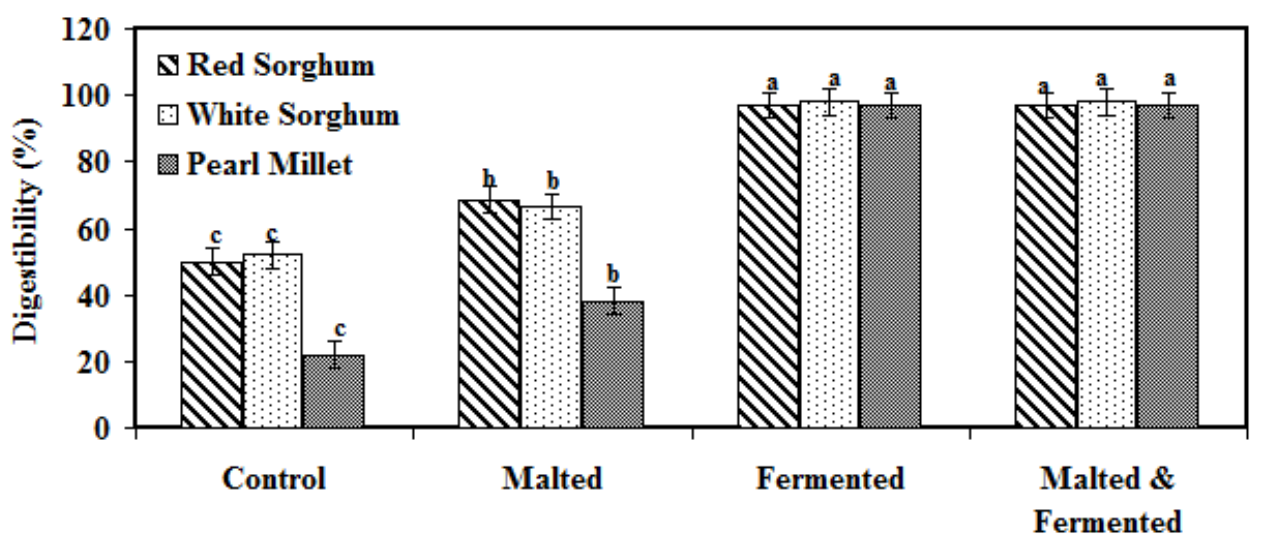

Treatments

Figure 3. Changes in protein digestibility after malting and fermentation of selected cereals for $24 \mathrm{hrs}$ (Cereals represented by the same letter(s) in the legend are not significantly different at $\mathrm{p} \leq 0.05$ )

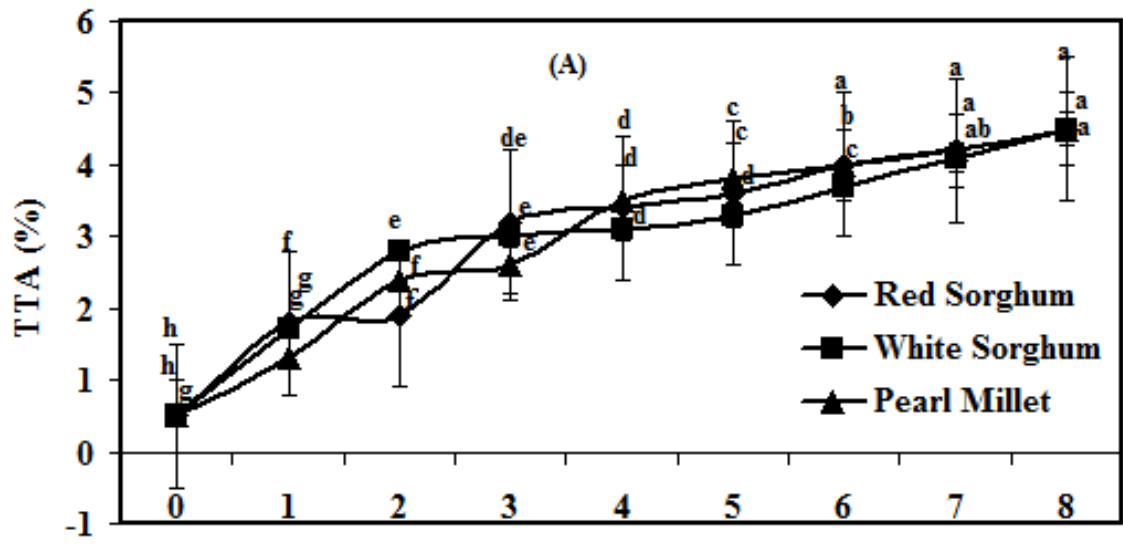

Fermentation Time (days)

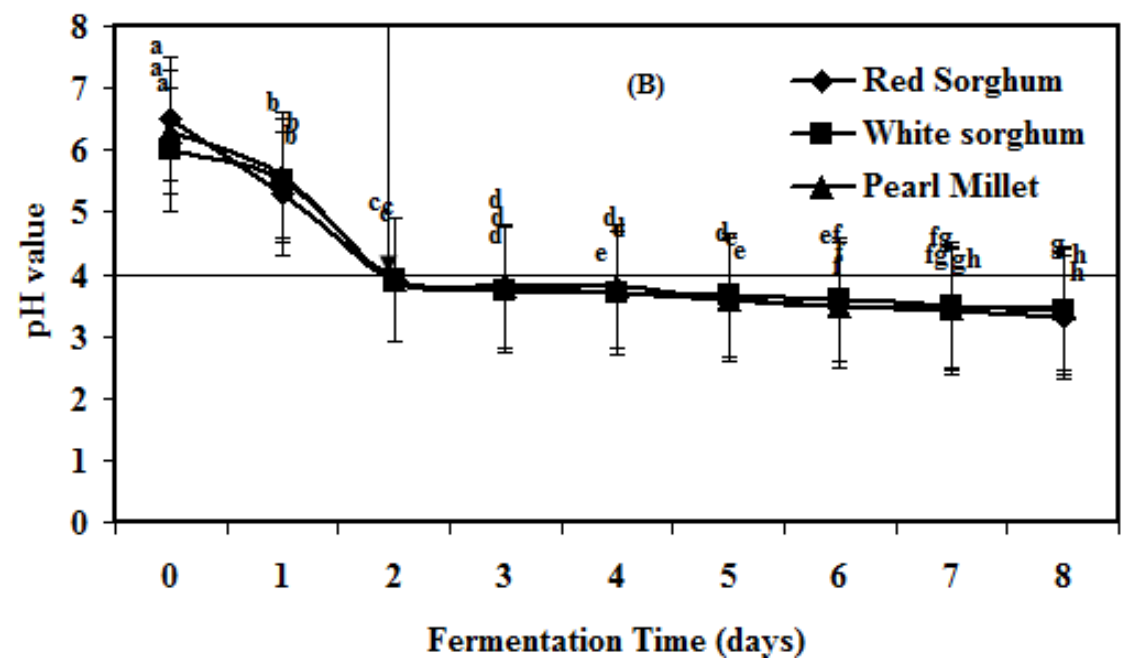

Figure 4. TTA (a) and $\mathrm{pH}$ (b) of cereal flours during fermentation for a period of 8 days

The vertical bars represent S.D of the means of 3 replicates. S.D $=$ Standard deviation. The horizontal line cutting across the chart shows the point where the $\mathrm{pH}$ values of 4 lies on the $\mathrm{pH}$ scale. The arrow indicates the time when $\mathrm{pH}$ value of 4 was attained. Points on the same curve with similar letter(s) have means that are not significantly different $(\mathrm{p} \leq 0.05)$. 
Pearl millet and red sorghum exhibited the highest reduction in $\mathrm{pH}$ from day 0 of fermentation. The $\mathrm{pH}$ drop in all the cereals was fast during the fermentation period of 8 days and the critical $\mathrm{pH}$ value of 4.0 was attained by the end of the second day. Fermentation to $\mathrm{pH}$ value of 4.0 and below is recommended in cereal flours and products meant for making thin porridges for complementary feeding of children. This helps in their preservation during storage due to the low $\mathrm{pH}$ levels which many microorganisms cannot withstand (Mbugua \& Njenga, 1991; Steinkraus, 1996). Further drop in $\mathrm{pH}$ serves the purpose of lowering the acidity and making the fermented mix more sour further altering the organoleptic properties of the ferments.

Similarly the TTA of the pearl millet and red sorghum cereals were correspondingly high. High acidity was thus critical and responsible for the low microbial load in the products during the storage period as seen later on in the microbial analysis section of the results. A secondary effect was in the alteration of the organoleptic properties of the cereal products that is imparting the sour acidic taste and aroma compounds (Steinkraus, 1983).

\section{Conclusion}

Malting and fermentation had several desirable effects on cereals. The processes decreased anti-nutrient levels and increased protein digestibility. Malting and fermentation were optimally done at $25^{\circ} \mathrm{C}$ for 3 days and 2 days respectively. Malting increased protein digestibility but to a significantly lower level than that of fermentation ( $\mathrm{p}$ $\leq$ 0.05). Malting and fermentation treatments can therefore be used singly or in combination as anti-nutrient detoxification treatments and at the same time nutrient enhancers by households and processors who use sorghum and millet.

\section{Acknowledgement}

The authors acknowledge the African institute for Capacity Development (AICAD) and Food Science Nutrition Network (FOSSNA) for funding the reseach and Jomo Kenyatta University of Agriculture and Technology (JKUAT) for availing research facilities from where this work was conducted.

\section{References}

Aliya, S., \& Geervan, P. (1981). An assessment of the protein quality of Vitamin B contents of commonly used fermented products of legumes and millets. Journal of Science, Food and Agriculture, 32, 837-842. http://dx.doi.org/10.1002/jsfa.2740320814

Annan, N. T., Poll, L., Sefa-Dedeh, S., Plahar, W. A., \& Jakobsen, M. (2003). Volatile compounds produced by Lactobacillus fermentum, Saccharomyces cerevisiae and Candida krusei in single starter culture fermentations of Ghananian maize dough. Journal of Applied Microbiology, 94(3), 462-474. http://dx.doi.org/10.1046/j.1365-2672.2003.01852.x

AOAC. (1995). Association of Official Analytical Chemists. Official methods of analysis (16th ed.). Gaithersburg, Maryland.

Au, P. M., \& Fields, M. L. (1981). A research note on nutritive quality of fermented sorghum. J. Food Sci., 46, 652-654.

Baghel, R. P. S., Netke, S. P., \& Bajpai, L. D. (1985). Nutritive value of kangni. Poultry Guide, 22, 28-29.

Beaumount, M. (2002). Flavouring composition prepared by fermentation with bacillus spp. International. Journal of Food Microbiology, 75, 189-196. http://dx.doi.org/10.1016/S0168-1605(01)00706-1

Burns, R. E. (1963). Methods of tannin analysis for forage crop evaluation. Georgia. Agricultural Experiment station Technical Bulletin, 32, 1-14.

Butler, L. G. (1988). The role of polyphenols in the utilization of ICRISAT-mandated grain crops and applications of biotechnology for improved utilization. In "Biotechnology in Tropical Crop Improvement". Proceedings of the International Biotechnology Workshop, Patancheru, India, 12-15 Jan. 1987, p. 147-152. Patancheru, ICRISAT.

Butler, L. G., Riedl, D. J., Lebryk, D. G., \& Blytt, H. J. (1984). Interaction of proteins with sorghum tannin: mechanism, specificity and significance. J. Am. Oil Chem. Soc., 61, 916-920. http://dx.doi.org/10.1007/BF02542166

Camacho, L., Sierra, C., Campos, R., \& Guzman, M. D. (1992). Nutritional changes caused by germination of legumes commonly eaten in Chile. Archives Latinoam Nutrition, 42, 283-90.

Camire, A. L., \& Clydesdale, M. (1982). Analysis of phytic acid in foods by HPLC. Journal of Food Science, 47, 576. http://dx.doi.org/10.1111/j.1365-2621.1982.tb10126.x 
Carter, E. G. A., \& Carpenter, K. J. (1981). Bound niacin in sorghum and its availability. Nutrition. Research, 1, 571-579. http://dx.doi.org/10.1016/S0271-5317(81)80087-5

Carter, E. G. A., \& Carpenter, K. J. (1982). The available niacin values of foods for rats and their relation to analytical values. Journal of Nutrition, 112, 2091-2103.

Dassenko, S. (1980). Effect of milling, fermentation and cooking on nutritive value of pearl millet (Pennisetum americanum (L) Leeke). PhD. thesis. Kansas State University, Manhattan, Kansas, Etats-Unis.

Deshpande, S. S., \& Salunke, D. K. (2002). Grain legumes, seeds and nuts: rationale for fermentation. Fermented grains legumes, seeds and nuts: A global perspective. FAO Agricultural Services Bulletin, 142, $1-32$.

Dhankher, N., \& Chauhan, B. M. (1987). Effect of temperature and fermentation time on phytic acid and polyphenol content of rabaadia fermented pearl millet food. Journal of Food Science, 5, 828-829. http://dx.doi.org/10.1111/j.1365-2621.1987.tb06739.x

Doggett, H. (1988). Sorghum Londres, Longman Scientific and Technical. In K. S. Dhindsa, S. Dhillon, \& Sood, D. R (Eds). Nutritional quality of millets. MILWAI News.

Egli, I., Davidsson, L., Juillerat, M. A., Barclay, D., \& Hurrell, R. (2002). The influence of soaking and germination on the phytase activity and phytic acid content of grains and seeds potentially useful for complementary feeding. Journal of Food Science, 67, 3484-3488. http://dx.doi.org/10.1111/j.1365-2621.2002.tb09609.x

Ejeta, G., Hassan, M. M., \& Mertz, E. T. (1987). In-vitro digestibility and amino acid composition of pearl millet (Pennisetum typhoides) and other cereals. Proc. Nat. Acad. Sci. USA.

FAO. (1995). Sorghums and millets in human nutrition. David Lubin memorial library publication.

ICRISAT. (1992). In M. J. Gomez (Ed.), Utilization of sorghums and millets.

Gibson, R. S. (1994). Zinc nutrition in developing countries. Nutrition Research Reviews, 7, 151-173. http://dx.doi.org/10.1079/NRR19940010

Hurrell, R. F. (2004). Phytic acid degradation as a means of improving iron absorption. International Journal of Vitamin Nutrition Research, 74, 445-452. http://dx.doi.org/10.1024/0300-9831.74.6.445

Lönnerdal, B., Sandberg A. S., Sandström, B., \& Kunz, C. (1989). Inhibitory effects of phytic acid and other inositol phosphates on zinc and calcium absorption in suckling rats. Journal of Nutrition, 119, 211-4

Mbugua, S. K., \& Njenga, J. (1991). The antimicrobial activity of fermented uji. Ecology of Food and Nutrition, 28, 191-198. http://dx.doi.org/10.1080/03670244.1992.9991270

Mertz, T. E., Hassan, M. M., Whittern, C. C., Kirleis, W. A., Tu. L., \& Axtell, D. J. (1984). Pepsin Digestibility of proteins in sorghum and other major cereals. Applied Biology, 81, 1-2.

Mosha, A. C. (1994). Nutritional improvement of sorghum by germination technology. In L. T., Marovatsanda, \& J. R. N. Taylor (Eds.), Food Science and technology challenges for Africa towards the year 2000 (pp. 162-174). Proceedings of the ECSAFOST Food Science and Technology Conference, 12-16 ${ }^{\text {th }}$ Sept. (1994). Victoria Falls Zimbabwe. University of Zimbabwe.

Ochanda, S. O, Onyango, C. A., Mwasaru, A. M., Ochieng, J. K., \& Mathooko, F. M. (2010). Effects of malting and fermentation on B-vitamins of red sorghum, white sorghum and pearl.

Ofori, F., \& Hahn, S. K. (1994). Tropical Root Crops. A developing economy. Proceedings of the $9^{\text {th }}$ symposium of the international Society for Tropical root Crops, pp. 20-26.

Price, M. L., Van Scoyoc, S. W., \& Butler, L. G. (1978). A critical evaluation of the vanillin reactions as an assay for tannins in sorghum grain. J. of Agric. Food Chem., 26, 1214-1218. http://dx.doi.org/10.1021/jf60219a031

Sandberg, A. S. (1991). The effect of food processing on phytate hydrolysis and availability of iron and zinc. In M. Friedman (Ed.), Nutritional and Toxicological Consequences of Food Processing (pp. 499-508). New York: Plenum Press.

Snedecor, G. W., \& Cochran, W. G. (1987). Statistical Methods (17 ${ }^{\text {th }}$ edn) (pp. 221-222). Ames, IA: The Iowa State University Press. 
Steinkraus, K. H. (1983). Lactic acid fermentation in the production of foods from vegetables, cereals and legumes. Antonine van Leeuwenhoek, 49, 337-348. http://dx.doi.org/10.1007/BF00399508

Steinkraus, K. H. (1996). Handbook of Indigenous Fermented Foods. New York: Marcel Dekker Inc.

Udayasekhara, P., \& Deosthale, Y. G. (1988). In vitro availability of iron and zinc in white and coloured ragi (Eleusine coracana): role of tannin and phytate. Plant Foods for Human Nutrition, 38, 35-41. http://dx.doi.org/10.1007/BF01092308

Vohra, P., Gray, G. A., \& Kratzer, F. H. (1965). Phytic acid-metal complexes. Proceedings of the Society for Experimental Biology and Medicine, 120, 447-449.

West, C. W., Eilander, A., \& Van Lieshout, M. (2002). Consequences of revised estimates of carotenoid bioefficacy for dietary control of vitamin A deficiency in developing countries. Journal of Nutrition, 132(9 Suppl), 2920S-2926S.

Yasmine, M. (2002). Impact of small scale fermentation technology on food safety in developing countries. $\begin{array}{lllll}\text { Intternational Journal of } & \text { Food }\end{array}$ http://dx.doi.org/10.1016/S0168-1605(01)00709-7 